\title{
Chemical constituents from Vellozia graminifolia (Velloziaceae)
}

\author{
ALEXSANDRO BRANCO $^{1}$, ANGELO C. PINTO ${ }^{1}$ and RAIMUNDO BRAZ FILHO ${ }^{2}$ \\ ${ }^{1}$ Instituto de Química, Departamento de Química Orgânica, Universidade Federal do Rio de Janeiro \\ 21949-970 Rio de Janeiro, RJ, Brasil \\ ${ }^{2}$ Setor de Química de Produtos Naturais-LCQUI-CCT, Universidade Estadual do Norte Fluminense \\ 28015-620 Campos, RJ, Brasil
}

Manuscript received on September 20, 2003; accepted for publication on December 1st, 2003; contributed by Angelo C. Pinto* ANd Raimundo Braz Filho*

\begin{abstract}
From the hexane and ethyl acetate extracts obtained from stems, roots and leaf sheaths of Vellozia graminifolia, a mixture of linear hydrocarbons, a mixture of pentacyclic triterpenes, five monoisoprenylated flavonoids and one labdane diterpene, (-)-ent-3 $\beta$-hydroxy-8(17)-labden-15-oic acid, were isolated. The linear hydrocarbons and minor triterpenes were identified in their corresponding mixtures by High Resolution Gas Chromatography (HRGC) and HRGC coupled to mass spectrometry. The major pentacyclic triterpenes and the diterpene were characterized by spectral data, including 2D NMR experiments, and chemical transformations.
\end{abstract}

Key words: Vellozia graminifolia, Velloziaceae, triterpenes, diterpene, flavonoids.

\section{INTRODUCTION}

Velloziaceae is a family of tropical monocotyledonous plants containing about 270 species, most of which occur in Brazilian tropical scrub on rock outcrops ("campos rupestres") (Stannard 1995). The Vellozia genus presents the largest number of species in the Velloziaceae family. Previous phytochemical studies showed that the main constituents of the Vellozia genus are flavonoids (Harborne et al. 1994, Williams et al. 1994), diterpenoids (Pinto et al. 1983, 1991, 1996a) and triterpenoids.

The triterpenoids reported in the literature as constituents of Vellozia species are distributed into the following classes: dammarane, lupane, taraxerane, oleanane and euphane (Barnes et al. 1984, Pinto et al. 1996b, Peixoto et al. 1979). The application of High Resolution Gas Chromatography

* Member of Academia Brasileira de Ciências

Correspondence to: Angelo C. Pinto

E-mail: angelo@iq.ufrj.br
(HRGC) and HRGC coupled to mass spectrometer (MS) can be used to distinguish its triterpenoids (Shiojima et al. 1992, Ogunkoya 1981) by retention time and fragmentation patterns, respectively. Thus, the identification of these compounds can be accomplished by co-injection in the HRGC using authentic samples isolated from other plants (Pinto et al. 1994, Patitucci et al. 1995). On the other hand, HRGC requires special attention in Velloziaceae because the presence of peaks corresponding to sterols (Peixoto et al. 1979) and dimmeric diterpenes (Pinto et al. 1997) can be observed in the same region where the triterpenes appear.

In continuation of our phytochemical studies with Vellozia graminifolia, we report in this paper the characterization of its pentacyclic triterpenes (1-15), in mixture, by high resolution HRGC and HRGC-MS, together with other spectral data. In addition, we also describe the struc- 
ture of a first labdane-type diterpene (16) from the Velloziaceae family, determined by application of NMR techniques, including Heteronuclear Multiple Quantum Coherence $\left({ }^{1} \mathrm{H}^{-13} \mathrm{C}-\mathrm{HMQC}-{ }^{1} J_{\mathrm{CH}},{ }^{1} \mathrm{H}\right.$ detected), Heteronuclear Multiple Bond Connectivity $\left[{ }^{1} \mathrm{H}_{-}{ }^{13} \mathrm{C}-\mathrm{HMBC}-{ }^{\mathrm{n}} J_{\mathrm{CH}}(\mathrm{n}=2\right.$ and 3$),{ }^{1} \mathrm{H}-$ detected] and Nuclear Overhauser Effect SpectroscopY (NOESY) (Nakanishi 1990, Sanders and Hunter 1993), and chemical transformations.

\section{MATERIALS AND METHODS}

\section{General Experimental Procedures}

Mps were uncorr. NMR spectra were recorded in $\mathrm{CDCl}_{3}$ soln at $300 \mathrm{MHz}$ for ${ }^{1} \mathrm{H}$ and $75 \mathrm{MHz}$ for ${ }^{13} \mathrm{C}$ on a Bruker $\mathrm{AC} 300$ spectrometer, using TMS as int. standard or by reference to the solvent signals: $\mathrm{CHCl}_{3}$ at $\delta_{\mathrm{H}} 7.25$ and $\mathrm{CHCl}_{3}$ at $\delta_{\mathrm{C}} 77.00$. HRGC analyses were recorded on a Hewlett Packard model 5790A gas chromatograph. Glass capillary column $(11 \mathrm{~m} \times 0.25 \mu \mathrm{m})$ coated with SE-54 $(\mathrm{df}=$ $0.25 \mu \mathrm{m})$. Analytical GC conditions: Hydrogen as carrier gas; flow rate of $2 \mathrm{ml} / \mathrm{min}$; injector port was set at $280^{\circ} \mathrm{C}$ and flame ionization detector (FID) at $290^{\circ} \mathrm{C}$. The temperature program for the analysis of mixtures ranged from $260^{\circ} \mathrm{C}$ to $280^{\circ} \mathrm{C}$. The data were collected on an HP 3396-II integrator. HRGCMS analyses were performed on an HP 5987A spectrometer (Hewlett Packard, Palo Alto, USA), with electron impact ionization $(70 \mathrm{eV})$. MS scan range was 40 to $700 \mathrm{Da}$. The GC-MS interface was at $350^{\circ} \mathrm{C}$ and ion source temperature at $300^{\circ} \mathrm{C}$. Column temperature program and injection mode were as for chromatographic analysis. CC: silica gel (0.063 to $0.2 \mathrm{~mm}$ ). TLC: silica gel (Merk, Kieselgel 60 ), spots visualized by UV (254 and $360 \mathrm{~nm}$ ) and exposure to $I_{2}$ vapor. TLC was used to analyze frs collected from CC.

\section{Plant Material}

The Vellozia graminifolia was collected in Chapada da Diamantina, Minas Gerais State, Brazil and identified by Prof. Nanuza L. de Menezes of the Universidade de São Paulo, São Paulo-SP, Brazil. A voucher of this plant is deposited in the herbarium of the Instituto de Botânica at the same university.

\section{EXTRACTION AND PURIFICATION}

Dried and powdered material (roots, stems and leaf sheaths) was successively extracted with n-hexane and ethyl acetate at room temp. and the solvents removed under vacuum to yield 12.9 and $13.9 \mathrm{~g}$ of oily residue, respectively. The n-hexane extract (12.9 g) was chromatographed on a column of silica gel (112 g) and eluted with hexane/EtOAc and EtOAc/MeOH mixtures in increasing polarity. A total of 29 fractions, each containing ca $120 \mathrm{~mL}$, were collected and combined on the basis of TLC comparative analysis. Fraction 1, eluted with hexane, afforded a mixture of alkanes. Fractions 4 and 5, eluted with hexane/EtOAc (3:1), furnished a mixture of pentacyclic triterpenes (1-15) (36 mg, as red oil) after removal of aliphatic esters with acetone. Fractions 10 and 11, eluted with hexane/EtOAc (2:1), yielded a mixture of $\mathbf{2 0}$ and 21. Fraction 20 eluted with EtOAc/MeOH (5:1) afforded 16 (48 mg), after recrystallization from acetone. The EtOAc extract $(13.90 \mathrm{~g})$ was chromatographed using the same procedures described above, yielding 22-24.

\section{MiXture of Alkanes}

Mp $57-58^{\circ} \mathrm{C}$. IR $v_{\max }^{\mathrm{KBr}} \mathrm{cm}^{-1}: 2960,2910,2820$ and $720\left(\mathrm{CH}_{3}, \mathrm{CH}_{2}\right)$. HRGC-MS $70 \mathrm{eV} \mathrm{m} / \mathrm{z}$ (rel. int.): $380\left([\mathrm{M}]^{\bullet+}, 3, \mathrm{C}_{27} \mathrm{H}_{56}\right) ; 394\left([\mathrm{M}]^{\bullet+}, 6, \mathrm{C}_{28} \mathrm{H}_{58}\right)$; $408\left([\mathrm{M}]^{\bullet+}, 3, \mathrm{C}_{29} \mathrm{H}_{60}\right) ; 422\left([\mathrm{M}]^{\bullet+}, 1, \mathrm{C}_{30} \mathrm{H}_{62}\right)$.

\section{Mixture of Pentacyclic Triterpenes}

IR $v_{\max }^{\mathrm{KBr}} \mathrm{cm}^{-1}: 1730(\mathrm{C}=\mathrm{O})$. HRGC chromatogram: Figure 1A. HRGC-MS $70 \mathrm{eV} \mathrm{m} / z$ (rel. int.): Table I. ${ }^{1} \mathrm{H}$ NMR (300 $\mathrm{MHz}, \mathrm{CDCl}_{3}$ ) and ${ }^{13} \mathrm{C}$ NMR (75 MHz, $\mathrm{CDCl}_{3}$ ): data for $\mathbf{2}$ and $\mathbf{8}$ in accordance with the literature data (Olea and Roque 1990, Mahato and Kundu 1994).

\section{(-)-Ent-3 $\beta$-HYDROXYLABD-8(17)-EN-15-OIC} ACID (16)

White crystal, $\mathrm{Mp} 144^{\circ} \mathrm{C},[\alpha]_{\mathrm{D}}-52^{\circ}\left(c 1.0, \mathrm{CHCl}_{3}\right)$. IR $v_{\max }^{\mathrm{KBr}} \mathrm{cm}^{-1}: 3300-2600(\mathrm{OH}), 1700(\mathrm{C}=\mathrm{O}), 1640$ 
TABLE I

Principal peaks observed in the mass spectra $(\mathrm{m} / \mathrm{z}$ and relative intensity in parenthesis) of the triterpenes isolated from $\mathrm{V}$. graminifolia.

\begin{tabular}{|c|c|c|c|c|c|}
\hline Peak* & $\mathrm{R}_{\mathrm{t}} * *$ & {$[\mathrm{M}]^{+\bullet}$} & {$[\mathrm{M}]^{+}-15$} & Principal peaks & Compound \\
\hline $\mathbf{a}$ & 24.4 & $422(100)$ & $407(15)$ & See Figure 2A & Olean-9(11),12-dien-3-one (1) \\
\hline b & 25.7 & $424(22)$ & 409 (14) & See Figure 2B & Taraxer-14-en-3-one (6) \\
\hline c & 26.1 & $424(11)$ & $409(10)$ & $\begin{array}{l}311(5) ; 205(100, \mathbf{8 a}) \\
189(26) ; 109(58) ; 95(44)\end{array}$ & neo-Lup-20(29)-en-3-one (7) \\
\hline d & 26.3 & $424(5)$ & $409(4)$ & $\begin{array}{l}391(2) ; 218(100, \mathbf{2 a}) ; 203 \\
(56,2 \mathbf{b}) ; 135(10) ; 55(24)\end{array}$ & Olean-12-en-3-one (2) \\
\hline $\mathbf{e}$ & 26.4 & $424(19)$ & $409(28)$ & See Figure 2C & Olean-18-en-3-one (3) \\
\hline $\mathbf{f}$ & 26.9 & $426(3)$ & $411(3)$ & $\begin{array}{l}281(11) ; 218(100, \mathbf{2 a}) ; \\
203(52) ; 107(26) ; 55(44)\end{array}$ & Olean-12-en-3-ol (5) \\
\hline g & 27.4 & $424(36)$ & $409(25)$ & $\begin{array}{l}381(6) ; 313(35) ; 245(25) ; \\
205(100,8 \mathbf{8 a}) ; 109(74)\end{array}$ & Lup-20(29)-en-3-one (8) \\
\hline $\mathbf{h}$ & 27.8 & $426(24)$ & $411(12)$ & $\begin{array}{l}393(10) ; 315(14) ; 207 \\
(90,9 a) ; 189(91,9 b) ; 107(68)\end{array}$ & Lup-20(29)-en-3 $\beta$-ol (9) \\
\hline i & 28.0 & $424(15)$ & $411(11)$ & $\begin{array}{l}313(18) ; 274(100, \mathbf{1 0 a}) ; 259 \\
(91, \mathbf{1 0 b}) ; 205(36) ; 109(86)\end{array}$ & Glutin-5-en-3-one (10) \\
\hline $\mathbf{j}$ & 28.6 & $438(30)$ & $423(12)$ & $\begin{array}{l}340(10) ; 313(44) ; 300(17) ; \\
175(36) ; 95(100)\end{array}$ & 24-methyl-cycloartan-25-en-3-one(12) \\
\hline 1 & 29.0 & $438(18)$ & $423(10)$ & $\begin{array}{l}409 \text { (38); } 395 \text { (9); } 313(12) ; \\
257 \text { (100); } 245 \text { (28) }\end{array}$ & - \\
\hline $\mathbf{m}$ & 29.4 & $438(12)$ & - & $\begin{array}{l}424(69) ; 408(11) ; 325(38) ; \\
205 \text { (100); } 189(82)\end{array}$ & - \\
\hline $\mathbf{n}$ & 29.6 & $438(8)$ & $423(6)$ & $\begin{array}{l}424(34) ; 355(28) ; 313(24) ; \\
205(100) ; 189(37)\end{array}$ & - \\
\hline $\mathbf{0}$ & 29.9 & $454(4)$ & $439(6)$ & $\begin{array}{l}259(8) ; 218(100, \mathbf{2 a}) ; 203 \\
(59, \mathbf{2 b}) ; 189(37) ; 95(40)\end{array}$ & Olean-12-en-3-one-23-oic acid (4) \\
\hline $\mathbf{p}$ & 30.1 & $454(5)$ & - & $\begin{array}{l}281(11) ; 274(100, \mathbf{1 0 a}) ; 259 \\
(92, \mathbf{1 0 b}) ; 231(31) ; 137(46)\end{array}$ & glutin-5-en-3-one-23-oic acid (11) \\
\hline $\mathbf{q}$ & 30.7 & $440(10)$ & $425(15)$ & $\begin{array}{l}409(73) ; 393(13) ; 271(22) ; \\
257 \text { (100); } 189(45)\end{array}$ & - \\
\hline $\mathbf{r}$ & 31.1 & $454(5)$ & $439(4)$ & $\begin{array}{l}385(5) ; 344(10) ; 218(100) ; \\
203(68) ; 189(22) ; 107(27)\end{array}$ & - \\
\hline $\mathbf{s}$ & 32.1 & $438(25)$ & $423(19)$ & See Figure 2D & Olean-12-en-3,11-dione (13) \\
\hline $\mathbf{t}$ & 33.3 & $438(28)$ & - & $\begin{array}{l}407(30) ; 313(23) ; 273 \\
(100, \mathbf{1 4 a}) ; 232(72, \mathbf{1 4 b}) \\
135(80, \mathbf{1 4 c})\end{array}$ & Ursan-12-en-3,11-dione (14) \\
\hline $\mathbf{u}$ & 33.7 & $440(13)$ & - & $\begin{array}{l}422(25) ; 407(14) ; 302(18) ; \\
217(35) ; 147(50) ; 95(100)\end{array}$ & 11-hydroxy-olean-12-en-3-one (15) \\
\hline
\end{tabular}

*Peak: see Figure 1B. **Retention Time in minute. 

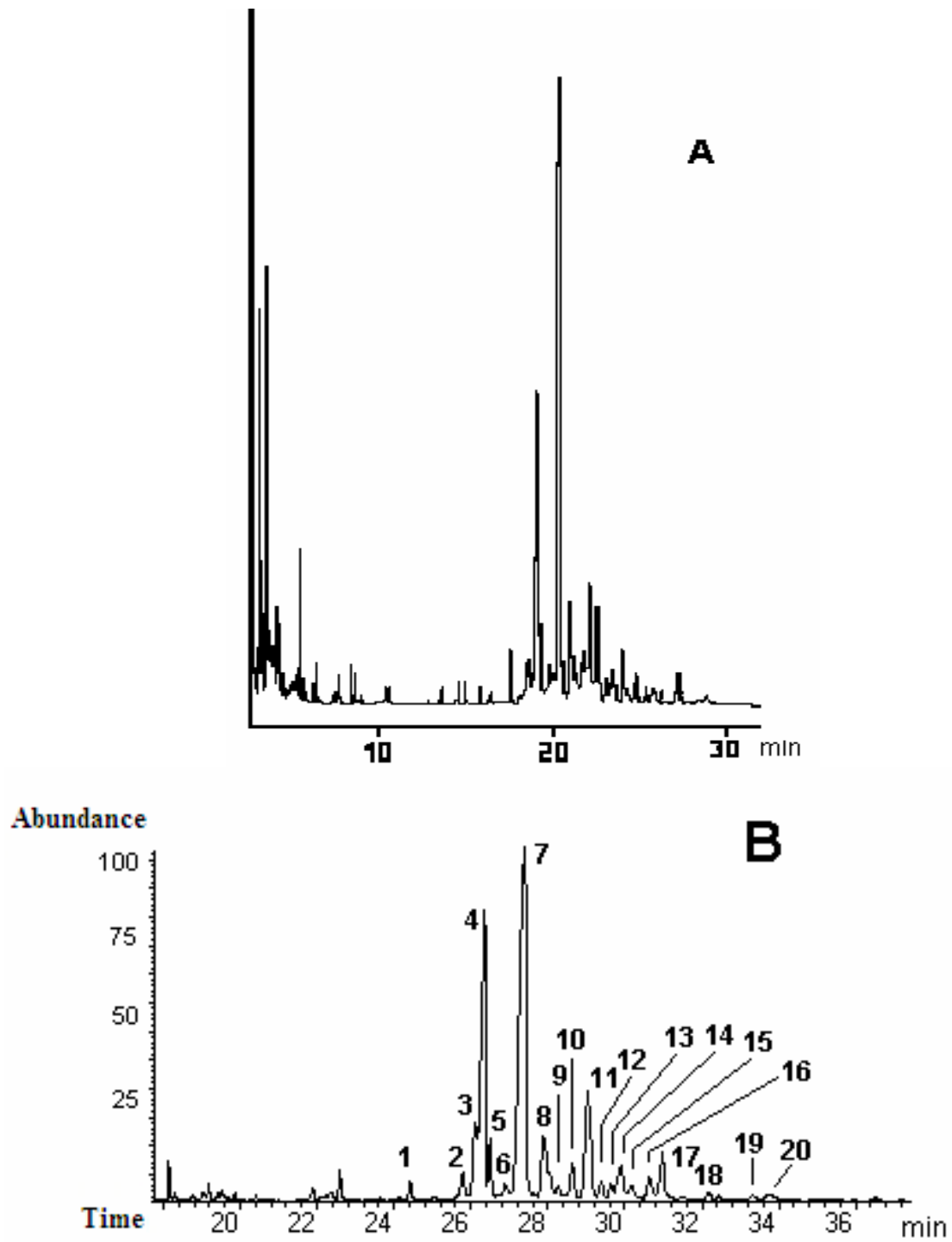

Fig. 1 - A) HRGC chromatogram of fraction containing pentacyclic triterpenes from $V$. graminifolia and B) Partial Total Ions Chromatogram (TIC) after recrystallization of the fraction. Mass spectra: see Table I.

and $850\left(\mathrm{C}=\mathrm{CH}_{2}\right) .{ }^{1} \mathrm{H}$ NMR $\left(300 \mathrm{MHz}, \mathrm{CDCl}_{3}\right)$ : $\delta_{\mathrm{H}} 0.66(s, 3 \mathrm{H}-20), 0.75(s, 3 \mathrm{H}-19), 0.95(d, J=$ $6.0,3 \mathrm{H}-16), 0.97(s, 3 \mathrm{H}-18), 1.70$ and $1.55(m, 2 \mathrm{H}-$ 2), 2.30 and $1.90(m, 2 \mathrm{H}-14), 3.23(d d, J=10.8$ and 4.1, H-3), $4.80(s, 1 \mathrm{H}-17)$ and $4.47(s, 1 \mathrm{H}-17)$. ${ }^{13} \mathrm{C}$ NMR $\left(75 \mathrm{MHz}, \mathrm{CDCl}_{3}\right): 35.6\left(\mathrm{CH}_{2}-1\right), 27.8$ $\left(\mathrm{CH}_{2}-2\right), 78.8(\mathrm{CH}-3), 39.0(\mathrm{C}-4), 51.5(\mathrm{CH}-5), 23.9$ $\left(\mathrm{CH}_{2}-6\right), 38.1\left(\mathrm{CH}_{2}-7\right), 148.0(\mathrm{C}-8), 56.5(\mathrm{CH}-9)$,
39.3 (C-10), $21.0\left(\mathrm{CH}_{2}-11\right), 37.0\left(\mathrm{CH}_{2}-12\right), 30.6$ (CH-13), $41.7\left(\mathrm{CH}_{2}-14\right), 178.6(\mathrm{C}-15), 19.5\left(\mathrm{CH}_{3}-\right.$ 16), 106.6 ( $\left.\mathrm{CH}_{2}-17\right), 28.2\left(\mathrm{CH}_{3}-18\right), 15.3\left(\mathrm{CH}_{3}-19\right)$, $14.4\left(\mathrm{CH}_{3}-20\right)$. EIMS $70 \mathrm{eV} \mathrm{m} / z$ (rel. int.): 322 $\left([\mathrm{M}]^{\bullet+}, 3\right), 307\left(\mathrm{M}-\mathrm{Me}^{\bullet}, 2\right), 304\left(\mathrm{M}-\mathrm{H}_{2} \mathrm{O}, 21\right), 289$ $\left(\mathrm{m} / \mathrm{z} 304-\mathrm{Me}^{\bullet}\right.$ and/or $\left.307-\mathrm{H}_{2} \mathrm{O}, 14\right), 245(\mathrm{~m} / \mathrm{z}$ $\left.304-{ }^{\bullet} \mathrm{CH}_{2} \mathrm{COOH}, 4\right), 193$ (16a, 5), 190 (16b, 5), 175 (16c, 21), 135 (16d, 100). 
Methyl Ent-3 $\beta$-HydRoXYlabd-8(17)EN-15-OATE (17)

The crystal of $\mathbf{1 6}(11.3 \mathrm{mg})$ was treated with $\mathrm{CH}_{2} \mathrm{~N}_{2}$ in the usual manner to yield $17(10.4 \mathrm{mg}) .{ }^{1} \mathrm{H}$ (300 MHz) and ${ }^{13} \mathrm{C}$ NMR (75 MHz, $\left.\mathrm{CDCl}_{3}\right)$ : Table II. EIMS $70 \mathrm{eV} \mathrm{m} / z$ (rel. int.): 336 ([M] ${ }^{\bullet+}$, 1), $321\left(\mathrm{M}-\mathrm{Me}^{\bullet}, 2\right), 318\left(\mathrm{M}-\mathrm{H}_{2} \mathrm{O}, 9\right), 303(\mathrm{~m} / \mathrm{z} 318$ - $\left.\mathrm{Me}^{\bullet}, 2\right), 193$ (4), 190 (5), 175 (m/z 193 - $\mathrm{H}_{2} \mathrm{O}$ and/or $\left.m / z 190-\mathrm{Me}^{\bullet}, 21\right), 135$ (16d, 100).

\section{Methyl ent-3-OXO-LABD-8(17)-EN-15-OATE (18)}

A soln of $16(10.7 \mathrm{mg})$ in $\mathrm{Me}_{2} \mathrm{CO}(10.0 \mathrm{~mL})$ was allowed to stand with slight excess of Jones' reagent at reflux for $2 \mathrm{hs}$ and usual work-up gave a colorless oil $18(7.2 \mathrm{mg})$ after methylation with $\mathrm{CH}_{2} \mathrm{~N}_{2} \cdot{ }^{1} \mathrm{H}$ NMR (300 MHz, $\left.\mathrm{CDCl}_{3}\right): \delta_{\mathrm{H}} 0.79(s, 3 \mathrm{H}-20), 0.95$ $(s, 3 \mathrm{H}-19), 0.88$ ( $d, J=6.6,3 \mathrm{H}-16), 1.02(s, 3 \mathrm{H}-18)$, $4.82(s, 1 \mathrm{H}-17)$ and $4.49(s, 1 \mathrm{H}-17)$. EIMS $70 \mathrm{eV}$ $m / z$ (rel. int.): 334 ([M] $\left.{ }^{\bullet+}, 45\right), 319$ (M - Me , 41), $303\left(\mathrm{M}-\mathrm{MeO}^{\bullet}, 24\right), 291$ ( $/$ / z 319 - CO, 15), 236 (18a, 11), 139 (18b,31), 123 (18c, 94).

\section{Ent-3 $\beta$-HYDROXYLABD-8(17)-EN-15-OL (19)}

The crystal of $\mathbf{1 6}(11.3 \mathrm{mg})$ was treated with $\mathrm{LiAlH}_{4}$ in the usual manner to yield $\mathbf{1 9}(10.4 \mathrm{mg})$. ${ }^{1} \mathrm{H}$ NMR $\left(300 \mathrm{MHz}, \mathrm{CDCl}_{3}\right): \delta_{\mathrm{H}} 0.68(s, 3 \mathrm{H}-20)$, 0.77 ( $s, 3 \mathrm{H}-19), 0.90$ ( $d, J=6.4,3 \mathrm{H}-16), 0.99$ $(s, 3 \mathrm{H}-18), 4.83(s, 1 \mathrm{H}-17)$ and $4.51(s, 1 \mathrm{H}-17)$, $3.62(\mathrm{~m}, 2 \mathrm{H}-15), 3.25(d d, J=11.6$ and $4.5, \mathrm{H}-$ 3). $\left.{ }^{13} \mathrm{C} \mathrm{NMR} \mathrm{(75} \mathrm{MHz,} \mathrm{CDCl}_{3}\right): 37.2\left(\mathrm{CH}_{2}-1\right)$, $28.0\left(\mathrm{CH}_{2}-2\right), 79.0(\mathrm{CH}-3), 39.2(\mathrm{C}-4), 54.7(\mathrm{CH}-5)$, $24.1\left(\mathrm{CH}_{2}-6\right), 38.3\left(\mathrm{CH}_{2}-7\right), 148.4(\mathrm{C}-8), 56.9(\mathrm{CH}-$ 9), 39.5 (C-10), $21.2\left(\mathrm{CH}_{2}-11\right), 36.3\left(\mathrm{CH}_{2}-12\right), 31.1$ (CH-13), $40.3\left(\mathrm{CH}_{2}-14\right), 61.3\left(\mathrm{CH}_{2}-15\right), 16.6\left(\mathrm{CH}_{3}-\right.$ 16), $106.8\left(\mathrm{CH}_{2}-17\right), 28.4\left(\mathrm{CH}_{3}-18\right), 15.5\left(\mathrm{CH}_{3}-19\right)$, $14.6\left(\mathrm{CH}_{3}-20\right)$. EIMS $70 \mathrm{eV} \mathrm{m} / z$ (rel. int.): 308 ([M] $\left.{ }^{\bullet+}, 6\right), 293\left(\mathrm{M}-\mathrm{Me}^{\bullet}, 4\right), 290(14), 275(\mathrm{~m} / z$ 290 - Me•, 6) 175 (15), 152 (16), 135 (16d, 100).

\section{Monoisoprenylated Flavonols (20-24)}

Spectral data have been described in previous papers (Branco et al. 1998, 2001, Branco 2001).

\section{RESULTS AND DISCUSSION}

The crude hexane extract from $V$. graminifolia was initially analyzed by HRGC and HRGC-MS. The previous knowledge of the heat stable chemical constituents present has been established for retention time $\left(\mathrm{R}_{\mathrm{t}}\right)$ and comparison of the mass spectral data with those of standards available in our laboratory. The complexity observed in the terpenoid eluting regions in the HRGC chromatogram led to fractionating on open silica gel column in the usual manner (see Experimental), yielding initially two fractions.

The presence of the $n$-alkanes $\left(\mathrm{C}_{27} \mathrm{H}_{56}\right.$ to $\mathrm{C}_{30} \mathrm{H}_{62}$ ) in the more apolar fraction (eluted with hexane) of the hexane extract have been determined on the basis of mass fragmentograms $(\mathrm{m} / z 57$ and 85) (Silverstein et al. 1995) obtained by HRGC-MS.

The HRGC chromatogram of the second fraction showed the presence of several compounds, containing two principal peaks with retention time 19.0 and $21.9 \mathrm{~min}$ (Figure 1A). This mixture was submitted to ${ }^{1} \mathrm{H}$ and ${ }^{13} \mathrm{C}$ NMR analysis involving comparison with literature data (Olea and Roque 1990, Mahato and Kundu 1994), allowing identification of the peaks as olean-12-en-3-one (2) and lup-20(29)-en-3-one (8), respectively. The $2 \mathrm{D}{ }^{1} \mathrm{H}$ ${ }^{13} \mathrm{C}-\mathrm{HMQC}-{ }^{1} J_{\mathrm{CH}}$ spectrum of the mixture revealed cross peaks consistent with the structures of these pentacyclic triterpenoids by heteronuclear coupling via one bond between the olefinic hydrogens $\mathrm{H}-12$ [2: $\delta_{\mathrm{H}} 5.25(\mathrm{~m})$ ] and 2H-29 [8: $4.56(\mathrm{br} s)$ and 4.68 $(b r s)]$ and the corresponding carbons $\mathrm{CH}-12$ of 2 $\left(\delta_{\mathrm{C}} 121.6\right)$ and $\mathrm{CH}_{2}-29$ of $8\left(\delta_{\mathrm{C}} 109.5\right)$.

\section{Minor Pentacyclic Triterpenes by HRGC-MS}

The fraction containing $\mathbf{2}$ and $\mathbf{8}$ was submitted to recrystallization to remove components in major percentage to improve the analysis of the minor components by HRGC-MS.

HRGC-MS analysis (Figure 1B) of the fraction obtained by the above procedure revealed the presence of the peaks in the mass spectra compatible with the fragmentation patterns of pentacyclic triterpenoids (Shiojima et al. 1992, Ogunkoya 1981). 
TABLE II

${ }^{1} \mathrm{H}(300 \mathrm{MHz})$ and ${ }^{13} \mathrm{C}(75 \mathrm{MHz})$ NMR spectral data for derivative $17\left(\mathrm{CDCl}_{3}\right)$, including results of heteronuclear 2D experiments ${ }^{1} \mathrm{H}_{-}{ }^{13} \mathrm{C}-\mathrm{COSY}-{ }^{n} \mathrm{~J}_{\mathrm{CH}}(\mathrm{n}=1, \mathrm{HMQC}$; $\mathrm{n}=\mathbf{2}$ and 3, HMBC).*

\begin{tabular}{|c|c|c|c|c|}
\hline \multicolumn{3}{|r|}{ HMQC } & \multicolumn{2}{|c|}{ HMBC } \\
\hline $\mathbf{C}$ & $\delta_{\mathrm{C}}$ & $\delta_{\mathrm{H}}$ & ${ }^{2} J_{\mathrm{CH}}$ & ${ }^{3} J_{\mathrm{CH}}$ \\
\hline 4 & 39.1 & - & H-3,3H-18,3H-19 & \\
\hline 8 & 148.1 & - & $\mathrm{H}-7, \mathrm{H}-9$ & $\mathrm{H}-11$ \\
\hline 10 & 39.4 & - & $3 \mathrm{H}-20, \mathrm{H}-5, \mathrm{H}-1$ & $\mathrm{H}-11$ \\
\hline 15 & 173.7 & - & $2 \mathrm{H}-14$ & $\mathrm{MeO}-15$ \\
\hline \multicolumn{5}{|l|}{$\mathbf{C H}$} \\
\hline 3 & 79.2 & $3.25(d d, J=11.7$ and 4.1) & $\mathrm{H}-2$ & $3 \mathrm{H}-18,3 \mathrm{H}-19, \mathrm{H}-1$ \\
\hline 5 & 54.9 & $1.08(d d, J=12.5$ and 2.0) & & H-1,3H-18,3H-19,3H-20 \\
\hline 9 & 57.0 & 1.54 & $\mathrm{H}-11$ & $2 \mathrm{H}-17,3 \mathrm{H}-20$ \\
\hline 13 & 31.2 & 1.92 & $2 \mathrm{H}-14,3 \mathrm{H}-16$ & \\
\hline \multicolumn{5}{|l|}{$\mathrm{CH}_{2}$} \\
\hline 1 & 37.4 & $\begin{array}{c}1.79 \\
1.17(d t, \quad J=13.2 \text { and } 3.8)\end{array}$ & & $3 \mathrm{H}-20$ \\
\hline 2 & 28.3 & $1.68 / 1.57$ & $\mathrm{H}-1$ & \\
\hline 6 & 24.3 & $1.74 / 1.36$ & H-7a,H-5 & \\
\hline 7 & 38.5 & $\begin{array}{c}2.39(b r d, \mathrm{~J}=12.5) \\
1.96(d t, \quad J=12.5 \text { and } 5.1)\end{array}$ & & $2 \mathrm{H}-17$ \\
\hline 11 & 21.3 & 1.42 & & \\
\hline 12 & 36.0 & $1.36 / 1.12$ & H-11 & $2 \mathrm{H}-14,3 \mathrm{H}-16$ \\
\hline 14 & 42.2 & $2.28(d d, J=6.2$ and 14.6) & $\mathrm{H}-13$ & \\
\hline & & $2.12(d d, \quad J=8.0$ and 14.6$)$ & & $3 \mathrm{H}-16$ \\
\hline 17 & 107.0 & $4.82(b r s) / 4.49(b r s)$ & & $\mathrm{H}-7$ \\
\hline \multicolumn{5}{|l|}{$\mathrm{CH}_{3}$} \\
\hline 16 & 19.8 & $0.94(d, J=6.6)$ & & $2 \mathrm{H}-14$ \\
\hline 18 & 28.6 & $0.99(s)$ & & H-3,3H-19 \\
\hline 19 & 15.7 & $0.77(s)$ & & H-3,3H-18 \\
\hline 20 & 14.8 & $0.68(s)$ & & $\mathrm{H}-1, \mathrm{H}-9$ \\
\hline $\mathrm{MeO}-15$ & 51.7 & $3.65(s)$ & & \\
\hline
\end{tabular}

*Chemical shifts $(\delta)$ and coupling constants ( $\mathrm{J}$ in $\mathrm{Hz}$, in parenthesis) obtained in the one-dimensional ${ }^{1} \mathrm{H}$ NMR spectrum. Number of hydrogens bound to carbon atoms deduced by comparative analysis of HBBD- and DEPT${ }^{13} \mathrm{C} .{ }^{1} \mathrm{H}-{ }^{1} \mathrm{H}-\mathrm{COSY} 2 \mathrm{D}$ NMR also used for these assignments.

The mass spectra of these compounds are summarized in Table I. The triterpene with retention time at $27.8 \mathrm{~min}$ (peak h, Figure 1B) was recognized as lup-20(29)-en-3 $\beta$-ol (9), which was confirmed by co-injection technique in HRGC using authentic sample (Patitucci et al. 1995)

The chromatographic profile observed by
HRGC-MS analysis showed in the chromatogram ion total (Figure 1B) two distinct patterns of elution to pentacyclic triterpenoids: monoxygenated (24 to $28 \mathrm{~min}$ ) and di- or trioxygenated (28 to $35 \mathrm{~min}$ ), respectively. This profile is similar to other triterpenes isolated from Vellozia species (Pinto et al. 1983, 1996a, 1991). On the basis of mass spectra analy- 

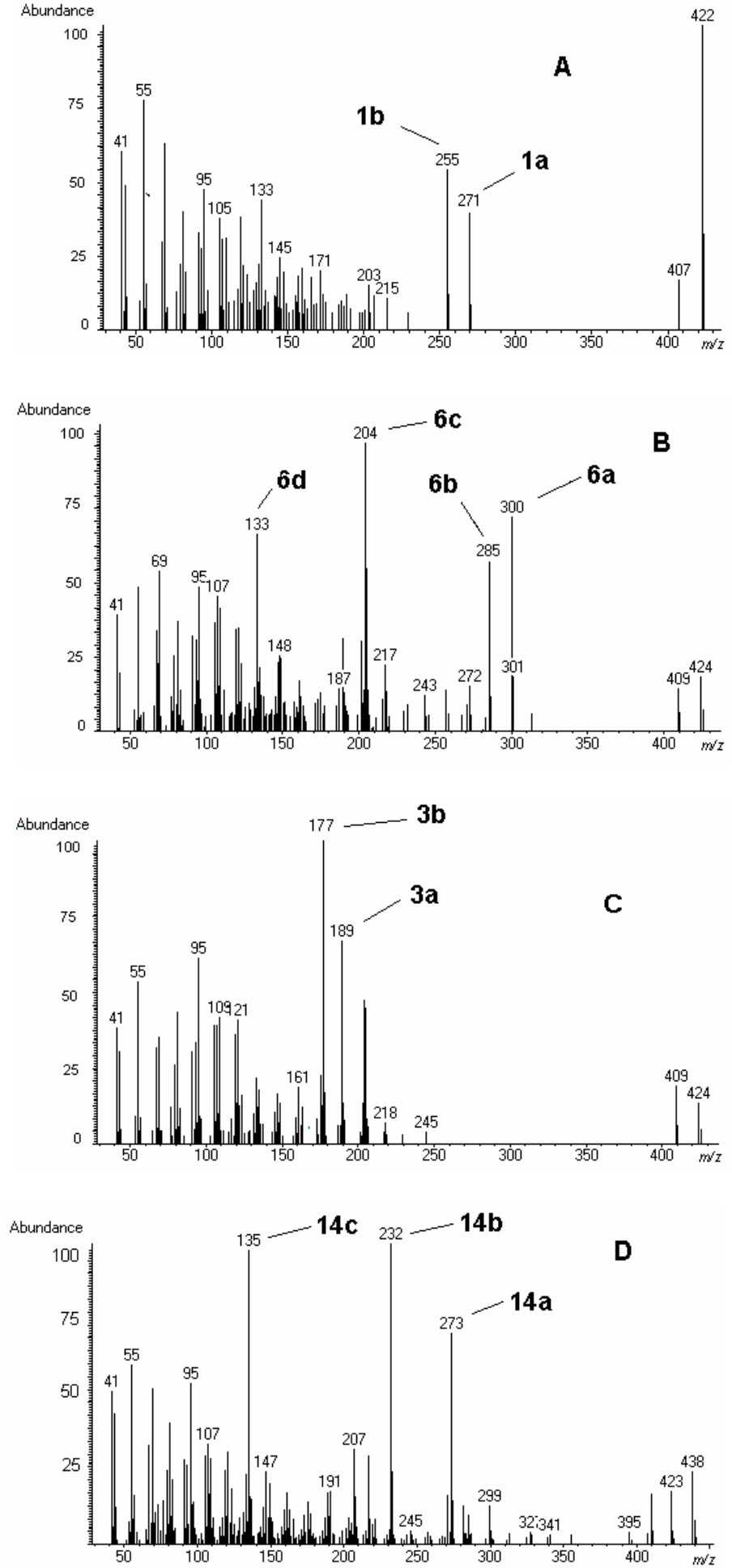

Fig. 2 - Mass spectra of some minor pentacyclic triterpenes: A) 1, B) 6, C) 3 and D) 13. Total Ion Chromatogram: see Figure 1B. 
sis, the compounds that appear at 24.4 (peak a), 25.7 (peak b), 26.1 (peak c), 26.4 (peak e), 26.9 (peak f), 28.0 (peak i) and 28.6 (peak j) min (Figure 1B and Table I) have been characterized as olean-9(11),12dien-3-one (1) (Barnes et al. 1984), taraxer-14-en3-one (6) (Sasaki et al. 1965), neo-lup-20(29)-en-3one (7) (Ageta et al. 1981), olean-18-en-3-one (3) (Budzikiewich et al. 1963), olean-12-en-3-ol (5) and glutin-5-en-3-one (10) (Shiojima et al. 1992), 24-methyl-cycloartan-25-en-3-one (12) (Kostova et al. 1997, Alves 2000), respectively. The 3-oxotriterpenes acid eluted at 29.9 (peak o) and 30.1 (peak p) min have been characterized as olean-12en-3-one-23-oic acid (4) and glutin-5-en-3-one-23oic acid (11), respectively.

The compounds eluted at 32.1 (peak s), 33.3 (peak t) and 33.7 (peak u) min, along with biogenetic considerations (Barnes et al. 1984, Torssell 1997), allowed postulating of the 13,14 and 15 , respectively, as probable structures. This conclusion was supported by peaks at $m / z 273(68 \%, 13 a$ and $100 \%$, 14a)/ $135(100 \%, \mathbf{1 3 c}$ and $80 \%, 14 c)$ and by peak at $m / z 232(100 \%, \mathbf{1 3 b}$ and $72 \%, \mathbf{1 4 b})$ in the mass spectra of the diketones, a characteristic and well documented peak due to retro-Diels-Alder fragmentation (Budzikiewich et al. 1963).

Thus, the above triterpenoids 1-15 (Figure 3 ) were identified by their mass spectra (Table I and Figure 4) and by comparison with standards previously isolated from species of Velloziaceae.

Obviously, pentacyclic triterpenoids of the ursane-type may be included as structural alternatives, since the occurrence of mixtures containing oleanane and ursane isomers is relatively common. Secondary biomodifications of triterpenes may involve the introduction of an additional hydroxyl group and double bond, oxidation of hydroxyl functions to carbonyl groups, reduction of double bond, Wagner-Meerwein rearrangement and alkylation by S-adenosyl methionine (Torssell 1997).

\section{Ent-3 $\beta$-HydroxylabD-8(17)-EN-15-OIC ACID (16)}

The IR spectrum of $\mathbf{1 6}$ revealed bands corresponding to a carboxylic acid function $\left(v_{\max } 3300\right.$ -
2600 and $\left.1700 \mathrm{~cm}^{-1}\right)$ and terminal methylene $\left(v_{\max }\right.$ 1640 and $\left.850 \mathrm{~cm}^{-1}\right)$. The signals corresponding to quaternary, methine, methylene and methyl carbon atoms were deduced by comparative analysis involving HBBD- and DEPT- ${ }^{13} \mathrm{C}$ NMR spectra. This analysis in combination with the low-resolution mass spectrum $\left(m / z 322[\mathrm{M}]^{+}\right)$and ${ }^{1} \mathrm{H}$ NMR spectra allowed the deduction of the molecular formula $\mathrm{C}_{20} \mathrm{H}_{34} \mathrm{O}_{3}=(\mathrm{C})_{2}\left(\mathrm{CH}_{2}\right)_{7}\left(\mathrm{CH}_{3}\right)_{4}(\mathrm{CH})_{4}\left(\mathrm{C}=\mathrm{CH}_{2}\right)$ $(\mathrm{COOH})(\mathrm{OH})$ for 16 . The peaks at $m / z 193(6 \%)$, $190(5 \%), 175(21 \%)$ and $135(100 \%)$ in the mass spectrum of 16, attributed to ionic fragment 16a, 16b, 16c and 16d, respectively, are characteristic of a diterpene with labdane skeleton oxygenated at C-3 (Figure 5).

The carboxyl function was confirmed by reaction with diazomethane, which furnished the methyl ester derivative 17. This derivative was also characterized by comparative analysis of the HBBD- and DEPT- ${ }^{13} \mathrm{C}$ NMR and ${ }^{1} \mathrm{H}$ NMR [1D and $2 \mathrm{D}{ }^{1} \mathrm{H}-$ ${ }^{1} \mathrm{H}$-COSY] spectra (Table II). The ${ }^{1} \mathrm{H}$ NMR spectra showed the presence of signals for an axial carbinolic hydrogen $\left[\delta_{\mathrm{H}} 3.25(d d, J=11.7\right.$ and $4.1 \mathrm{~Hz})$, $\mathrm{H}-3]$, two terminal methylidene hydrogens $\left[\delta_{\mathrm{H}} 4.82\right.$ (br s) and 4.49 (br s), 2H-17] and four methyl groups: three tertiary at $\delta_{\mathrm{H}} 0.68(s), 0.77(s)$ and $0.99(s)$, and one secondary at $\delta_{\mathrm{H}} 0.94(d, J=$ $6.6 \mathrm{~Hz})$.

2D shift-correlated NMR techniques ${ }^{1} \mathrm{H}_{-}{ }^{13} \mathrm{C}$ HMQC- ${ }^{1} J_{\mathrm{CH}}$ and ${ }^{1} \mathrm{H}_{-}{ }^{13} \mathrm{C}-\mathrm{HMBC}-{ }^{n} J_{\mathrm{CH}}$ (Table II) and ${ }^{1} \mathrm{H}-{ }^{1} \mathrm{H}-\mathrm{NOESY}$ (Table III) of the methyl ester derivative 17 were also used for the correct ${ }^{1} \mathrm{H}$ and ${ }^{13} \mathrm{C}$ NMR chemical shift assignments and stereochemistry deductions of the natural diterpene $\mathbf{1 6}$. The HMBC spectrum revealed the long-range heteronuclear couplings between C-8 $\left(\delta_{\mathrm{C}} 148.1\right)$ and the hydrogen atoms $2 \mathrm{H}-11\left[\delta_{\mathrm{H}} 1.42,{ }^{3} J_{\mathrm{CH}}\right], 2 \mathrm{H}-7$ $\left[2.39(b r d, J=12.5),{ }^{2} J_{\mathrm{CH}}\right]$ and $\mathrm{H}-9\left(1.54,{ }^{2} J_{\mathrm{CH}}\right)$.

The oxidation with Jones' reagent of $\mathbf{1 7}$ yielded the methyl 3-oxo-labd-8(17)-en-15-oate (18), which was characterized on the basis of spectral data (Experimental).

The diol 19 was obtained by reaction of 17 with $\mathrm{LiAlH}_{4}$. The ${ }^{1} \mathrm{H}$ NMR spectrum of $\mathbf{1 9}$ showed the 


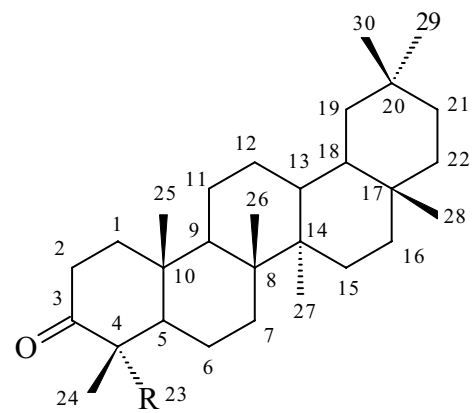

$\mathbf{R}$

$1 \Delta^{9(11), 12} \mathrm{CH}_{3}$

$2 \Delta^{12} \quad \mathrm{CH}_{3}$

$3 \Delta^{18} \quad \mathrm{CH}_{3}$

$4 \Delta^{12} \quad \mathrm{CO}_{2} \mathrm{H}$<smiles>CC1(C)CCC2(C)CC[C@]3(C)C(=CCC4[C@@]5(C)CCC(O)C(C)(C)C5CC[C@]43C)C2C1</smiles>

5<smiles>C=C(C)C1CCC2(C)CC[C@]3(C)C(CCC4[C@@]5(C)CCC(=O)C(C)(C)C5CC[C@]43C)C12</smiles><smiles>CC1(C)CCC2(C)CC=C3[C@](C)(CCC4[C@@]3(C)CCC3C(C)(C)C(=O)CC[C@@]34C)C2C1</smiles>

6

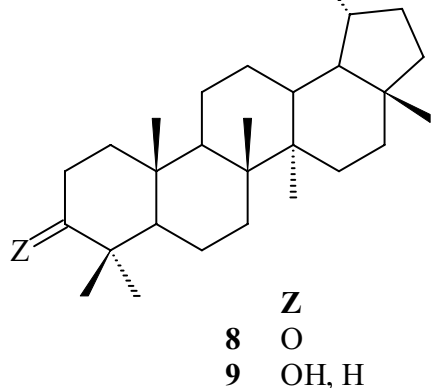

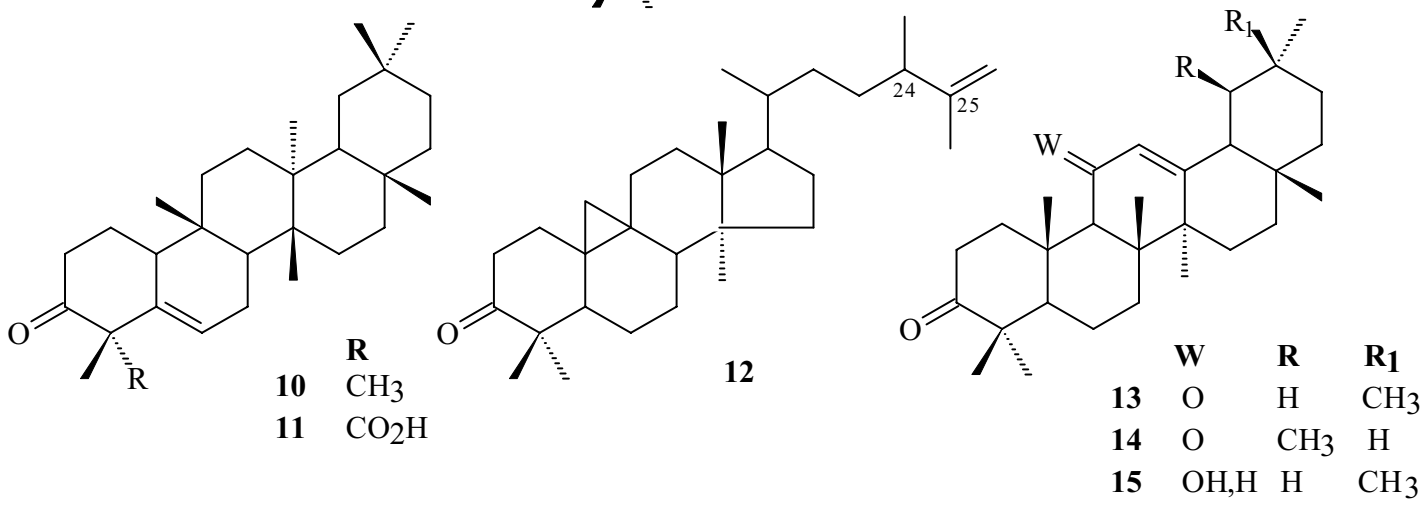

Fig. 3 - Structures of the Triterpenoids characterized in the V. graminifolia.

presence of the signal corresponding to hydrogens of a hydroxymethylene group at $\delta_{\mathrm{H}} 3.62(\mathrm{~m})$. The molecular ion at $m / z 308$ observed in the mass spectrum was also used to characterize the structure of this diol. The negative optical rotation compared with the recently synthesized (+)-3 $\beta$-hydroxylabd8(17)-ene-15-ol (Pemp and Seifert 1997) allowed determination of $\mathbf{1 9}$ as an ent-labdane.

Thus, the natural diterpene isolated from Vellozia graminifolia was characterized as (-)-3 $\beta$ hydroxylabd-8(17)-en-15-oic acid (16). To the best of our knowledge 16, is the first diterpene with a labdane skeleton from the Velloziaceae family; its enantiomer was isolated from Araucaria imbricata (Chandra et al. 1964) and from Moldenhawera nutans (David et al. 1998).

\section{Monoisoprenylated Flavonols}

The structures of the new prenylated flavonols (20-22) (Figure 6) have been identified on the basis of spectral analysis, including 2D NMR techniques 
<smiles>CCC1C=CC=C2C1CCC1C(C)(C)C(=O)CCC21C</smiles>

1a $m / z 271$<smiles>C=C1C=CC=C2[C]1CCC1C(C)(C)C(=O)CC[C@]21C</smiles>

$1 \mathbf{b} \mathrm{m} / \mathrm{z} 255$<smiles>C=CC1=C(C)CCC2(C)CC[C@](C)(C[18F])CC12</smiles>

2a $m / z 218$<smiles>C=CC1=C(C)CC[C+]2CCC(C)(C)CC12</smiles>

2b $m / z 203$

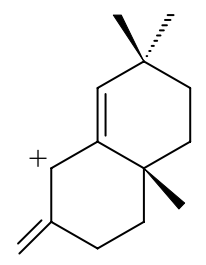

3a $m / z 189$<smiles>CC1=CC2=CC(C)(C)CC[C+]2CC1</smiles>

3b $m / z 177$<smiles>C=CC1=C(C)CCC2C(C[PH3+])C3(C)CCC(=O)C(C)(C)C3CCC12C</smiles>

6a $m / z 300$<smiles>C=CC1=C(C)CCC2[C@@H]1CCC1C(C)(C)C(=O)CC[C@@]21C</smiles>

6b $m / 2285$<smiles>C=CC1=C(C)CCC2C(C)CCCC12C(C)(C)C</smiles>

6c $m / z 204$<smiles>C=C1CCC2C(C)(C)C=CCC2(C)C1</smiles>

9b $m / z 189$<smiles>C=CC1=C(C)CC=C[C+]1C</smiles>

6d $m / z 133$<smiles>C[C@H]1CC[C@H]2C3CC(C)(C)CCC3(C)CC[C@]2(C)C1</smiles>

10a $m / z 274$<smiles>C=C1CCC2C(C)(CCC(=O)C2(C)C)C1</smiles>

8a $m / z 205$<smiles>C[C@H]1C=C2CCC3(C)CCC(C)(C)CC3C2CC1</smiles>

10b $\mathrm{m} / z 259$<smiles>C=C1[CH]C2(C)CCC(O)C(C)(C)C2CC1</smiles>

9a $m / z 207$<smiles>[R]C1C2C(=CC(O)=C[C@H]2C)[C@@]2(C)CC[C@]3(C)CC[C@]([R])(C)[C@@H]3[C@H]12</smiles>

R $\quad \mathbf{R}_{\mathbf{1}}$

$\begin{array}{llll}\text { 13a } & \mathrm{H} & \mathrm{CH}_{3} & m / z\end{array} 273$

14a $\mathrm{CH}_{3} \quad \mathrm{H} \quad m / z 273$<smiles>[R]C1C2C(C=C=O)=C(C)CC[C@]2(C)CC[C@]1([R])C[I+](C)C</smiles>

R $\mathbf{R}_{\mathbf{1}}$

13b $\quad \mathrm{H} \quad \mathrm{CH}_{3} \quad \mathrm{~m} / z 232$

14b $\quad \mathrm{CH}_{3} \quad \mathrm{H} \quad \mathrm{m} / \mathrm{z} 232$<smiles></smiles>

13c/14c $\mathrm{m} / \mathrm{z} 135$

Fig. 4 - Ionic fragments corresponding to principal peaks observed in the mass spectra. Obviously, the ionic fragments that appear with numbers and letters to indicate the triterpene correspondents can be used for other triterpenoids if compatible. 


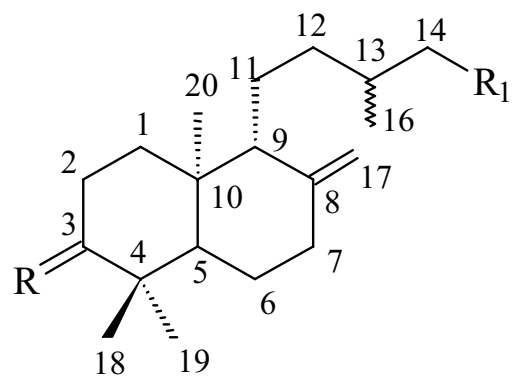
$\begin{array}{lll}\mathbf{R} & \mathbf{R}_{1}\end{array}$
$16 \beta \mathrm{OH}, \mathrm{H} \quad \mathrm{CO}_{2} \mathrm{H}$
$17 \quad \beta \mathrm{OH}, \mathrm{H} \quad \mathrm{CO}_{2} \mathrm{Me}$
$18 \mathrm{O} \quad \mathrm{CO}_{2} \mathrm{Me}$
$19 \beta \mathrm{OH}, \mathrm{H} \quad \mathrm{CH}_{2} \mathrm{OH}$<smiles>CC1=C[C+]2CC[C@@H](O)C(C)(C)C2CC1</smiles>

$16 \mathbf{a}(\mathrm{m} / \mathrm{z} 193)$<smiles>CCC1=C[C@@]2(C)CC=CC(C)(C)C2CC1</smiles>

16b $(m / z 190)$<smiles>CC1=C[C@H]2CC=CC(C)(C)C2CC1</smiles>

$16 \mathbf{c}(m / z$ 175)<smiles>C=C1[C+](C)CC=CC1(C)C</smiles>

16d $(m / z 135)$<smiles>CCCCC(=O)C[C@H]1C=C2CCC=C(C)[C@H]2CC1</smiles>

18a $(\mathrm{m} / z 236)$<smiles>C[C@H]1CCC(=O)C(C)(C)C1</smiles>

$\mathbf{1 8 b}(\mathrm{m} / z$ 139)<smiles>CC1=C[C+](C)CC=C1O</smiles>

$18 c(m / z 123)$

Fig. 5 - Structure of the labdane diterpenoid 16, derivatives 17-19 (upper) and their ionic fragments corresponding to principal peaks observed in the mass spectra (lower).

such as HMQC, HMBC and NOESY, together with chemical shift correlations (Branco et al. 1998, 2001, Branco 2001). The additional new flavonoids 23 and 24 were characterized by HT-HRGC (high temperature high resolution gas chromatography) and HT-HRGC coupled to mass spectrometry experiments (Branco et al. 2001, Branco 2001).

\section{ACKNOWLEDGMENTS}

The authors are grateful to Conselho Nacional de Desenvolvimento Científico e Tecnológico (CNPq), Financiadora de Estudos e Projetos (FINEP)/Programa de Apoio ao Desenvolvimento Científico e Tecnológico (PADCT), Coordenação de Aperfeiçoamento de Pessoal Nível Superior (CAPES) and 
<smiles>[R]c1c(-c2ccc(OC)c(OC)c2)oc2cc3c(c(O)c2c1=O)CC(C(=C)C)O3</smiles>

$\begin{array}{ll} & \text { R } \\ \mathbf{2 0} & \mathrm{H} \\ \mathbf{2 1} & \mathrm{Me}\end{array}$<smiles>[R]c1cc(-c2oc3cc4c(c(OC)c3c(=O)c2OC)CC(C(=C)C)O4)ccc1OC</smiles>

$\mathbf{R}$

$22 \mathrm{OH}$

$23 \mathrm{OMe}$

$24 \mathrm{H}$

Fig. 6 - Structures of the Monoisoprenylated flavonols isolated from V. graminifolia.

\section{TABLE III}

${ }^{1}{ }^{H}-{ }^{1}$ H-NOESY (dipolar couplings) spectral data for $17\left(300 \mathrm{MHz}, \mathrm{CDCl}_{3}, \delta\right)$.

\begin{tabular}{c|c|c|l}
\hline $\mathrm{H}$ & $\delta_{\mathrm{H}}$ & $\mathrm{H}$ & $\delta_{\mathrm{H}}$ \\
\hline $17 \mathrm{a}$ & 4.82 & $7 \mathrm{eq}$ & 2.39 \\
\hline $17 \mathrm{~b}$ & 4.49 & 11 & 1.42 \\
\hline 3 & 3.25 & $2 \mathrm{eq}$ & 1.68 \\
& & $1 \mathrm{ax}$ & 1.17 \\
& & 5 & 1.08 \\
& & 18 & 0.99 \\
\hline 9 & 1.54 & 5 & 1.08 \\
\hline 18 & 0.99 & $6 \mathrm{eq}$ & 1.74 \\
& & 5 & 1.08 \\
& & 19 & 0.77 \\
\hline 19 & 0.77 & $2 \mathrm{ax}$ & 1.57 \\
& & $6 \mathrm{ax}$ & 1.36 \\
& & 18 & 0.99 \\
& & 20 & 0.68 \\
\hline 20 & 0.68 & $2 \mathrm{ax}$ & 1.57 \\
& & $6 \mathrm{ax}$ & 1.36 \\
& & 11 & 1.42 \\
& & 19 & 0.77 \\
\hline
\end{tabular}

Fundação de Amparo à Pesquisa do Estado do Rio de Janeiro (FAPERJ) for grants and fellowships (CNPq). Thanks are also due to Professora Nanuza L. de Menezes (Instituto de Biologia, Universidade de São Paulo, São Paulo, Brazil) for plant identification.

\section{RESUMO}

Dos extratos em hexano e em acetato de etila obtidos a partir de caules, raízes e bainhas foliares de Vellozia graminifolia foram identificados hidrocarbonetos lineares, uma mistura de triterpenos pentacíclicos, cinco flavonóides monoisoprenilados e um diterpeno com esqueleto labdano, o ácido (-) -ent-3 $\beta$-hidroxi-8(17)-labdeno-15-óico. Este é o primeiro diterpeno com esqueleto labdano isolado da família Velloziaceae.

A identificação dos hidrocarbonetos lineares e dos triterpenos minoritários presentes nas duas misturas isoladas foi realizada por Cromatografia Gasosa de Alta Resolução (CGAR) e CGAR acoplada a espectrometria de massas. A determinação estrutural dos triterpenos pentacíclicos majoritários e do diterpeno foi realizada por dados espectrais, incluindo RMN 2D, e transformações químicas. As estruturas dos flavonóides monoisoprenilados são discutidas em artigos anteriores.

Palavras-chave: Vellozia graminifolia, Velloziaceae, triterpenos, diterpeno, flavonóides.

\section{REFERENCES}

Ageta H, Shiojima K, Masuda K and Lin T. 1981. Composite constituents: four new triterpenoids, neolupenol, tarolupenol and their acetates isolated from roots of a japonese dandelion, Taraxacum japonicum. Tetrahedron Lett 22: 2289-2290.

Alves AB. 2000. Constituintes químicos de Burlemax rodrigues Menezes e Semir (Velloziaceae). Msc Thesis, Universidade Federal do Rio de Janeiro, Instituto de Química, 156p. 
Barnes RA, Pereira AL, Scofield TCV, Braz-Filho R AND Pinto AC. 1984. A new triterpene from Vellozia compacta. Chem Pharm Bull 32: 3674-3677.

Branco A. 2001. Flavonóides C-alquilados obtidos de extratos apolares de Velloziaceae. Dsc Thesis, Universidade Federal do Rio de Janeiro, Instituto de Química, 2001, 358p.

Branco A, Braz-Filho R, Kaiser CR and Pinto AC. 1998. Two monoisoprenylated flavonoids from Vellozia graminifolia. Phytochemistry 47: 471-474.

Branco A, Pereira AP, Cardoso JN, Aquino-Neto FR, Pinto AC and Braz-Filho R. 2001. Further lipophilic flavonols in Vellozia graminifolia (Velloziaceae) by high temperature gas chromatography: quick detection of new compounds. Phytochem Anal 12: 266-270.

Budzikiewich H, Wilson JM and Djerassi C. 1963. Mass spectrometry in structural and stereochemical problems XXXII. Pentacyclic triterpenes. J Am Chem Soc 85: 3688-3699.

Chandra G, Clark J, Mclean J, Pauson Pl and Watson J. 1964. New diterpenes from Araucaria imbricata. J Chem Soc: 3648-3654.

David JP, David JM, YANG S-W ANd CoRdell GA. 1998. A bis-labdenic diterpene from Moldenhawera nutans. Phytochemistry 50: 443-447.

Harborne JB, Williams CA, Greenham J and Eagles J. 1994. Variations in the lipophilic flavonoids of the genus Vellozia. Phytochemistry 35: 1475-1480.

Kostova I, Ivanova A And Budzikiewicz H. 1997. Linked scan measurements for the localization of side-chain double bonds in 9,19-cyclopropano steroids. J Mass Spectrom 32: 1317-1319.

Mahato SB AND Kundu A. 1994. ${ }^{13}$ C NMR spectra of pentacyclic triterpenoids - a compilation and some salient features. Phytochemistry 37: 1517-1575.

NAKANISHI K. (Editor) 1990. One-dimensional and Twodimensional NMR Spectra by Modern Pulse Techniques, California: University Science Books.

OgunKoya L. 1981. Application of mass spectrometry in structural problems in triterpenes. Phytochemistry 20: 121-126.

Olea RSG AND Roque NF. 1990. Análise de misturas de triterpenos por RMN de 13C. Quím Nova 13: $278-281$.
Patitucci ML, Pinto AC and Cardoso JN. 1995. Analysis of crude extracts and fractions of Brazilian Polypodiaceae by high-resolution gas chromatographymass spectrometry I. Triterpenes. Phytochem Anal 6: $38-44$.

Peixoto EM, Pinchin R and Pinto AC. 1979. Constituintes químicos de Vellozia piresiana. Ciênc Cult (Suplemento): 125-127.

Pemp A AND Seifert K. 1997. Enantioselective total synthesis of (+)-labd-8(17)-ene-3 $\beta, 15$-diol and (-)labd-8(17)-ene-3 $\beta, 7 \alpha, 15$-triol. Tetrahedron Lett 38: 2081-2084

Pinto AC, Scofield TCV and Braz-Filho R. 1983. Two new diterpenes with a rosane skeleton from Velloziaceae. Tetrahedron Lett 24: 5043-5046.

Pinto AC, QueIroz PPS and Garcez W. 1991. Diterpenes from Vellozia bicolor. J Braz Chem Soc 2: 25-30

Pinto AC, Simoni Mlpsc, Cunha SC, Coelho RB, Patitucci ML and Lago RCA. 1994. Misturas naturais de esteróides, uma alternativa para aplicação de padrões em análises por cromatografia gasosa de alta resolução. Quím Nova 17: 333-335.

Pinto AC, Rezende CM, Antunes OAC and Correia CRD. 1996a. Three isomeric diterpenes from Vellozia flavicans. Phytochemistry 42: 767-769.

Pinto AC, Antunes OAC, Pizzolatti MG and RumJANEK VM. 1996b. A tetranorfriedolabdane diterpene from Vellozia stipitata. Phytochemistry 42: 771-774.

Pinto AC, Pizzolatti MG, Epifanio RA, Frankmolle W and Fenical W. 1997. The isolation of novel diterpenoids, including a $\mathrm{C} 40$ bis-diterpenoid, from the brazilian plant Vellozia magdalenae (Velloziaceae). Tetrahedron 53: 2005-2012.

SANDERS JKM AND HunTER BK. 1993. Modern NMR Spectroscopy: A Guide for Chemists, $2^{\text {nd }}$ ed., Oxford: Oxford University Press.

Sasaki S, Aoyagi S and Hsu H-Y. 1965. The isolation of taraxerol, taraxeryl acetate and taraxerone from Crossostephium chinense Makino (Compositae). Chem Pharm Bull 13: 87-88.

Shiojima K, Arai Y, Masuda K, Takase Y, Ageta T And Ageta H. 1992. Mass spectra of pentacyclic triterpenoids. Chem Pharm Bull 40: 1683-1690. 
Silverstein RM, Bassler GC ANd Morril TC. 1995. Identificação espectrométrica de compostos orgânicos, 5a. ed., Rio de Janeiro: Guanabara Koogan, $387 \mathrm{p}$.

StANNARd BL. 1995. Flora of the Pico das Almas: Chapada da Diamantina, Great Britain: Whitstable Litho Ltd, p. 43-78.
Torssell KBC. 1997. Natural Product Chemistry-A mechanistic, biosynthetic and ecological approach, $2^{\text {nd }}$ ed., Sweden: Swedish Pharmaceutical Press, $p$ 283-292.

Williams CA, Harborne JB, Greenham J and Eagles J. 1994. Differences in flavonoids patterns between genera within the Velloziaceae. Phytochemistry 36: 931-940. 